\title{
Dynamics of gonadal development of Aegla platensis Schmitt (Decapoda, Anomura, Aeglidae)
}

\author{
Carolina C. Sokolowicz; Georgina Bond-Buckup \& Ludwig Buckup
}

Programa de Pós-Graduação em Biologia Animal, Departamento de Zoologia, Instituto de Biociências, Universidade Federal do Rio Grande do Sul. Avenida Bento Gonçalves 9500, Prédio 43435, 91501-970 Porto Alegre, Rio Grande do Sul, Brasil.

\begin{abstract}
One way to estimate gonadal development through the reproductive cycle is to observe the growth of the gonads related to the organs used to store energy. The aim of this study was to follow the gonadosomatic and hepatosomatic indexes during annual cycle of Aegla platensis Schmitt, 1942. Adult animals were collected in Taquara, Rio Grande do Sul, Brazil $\left(29^{\circ} 46^{\prime}\right.$ S, $\left.50^{\circ} 53^{\prime} \mathrm{W}\right)$. Males and females were initially weighed and dissected and had their gonads and hepatopancreas (HP) removed and weighed in order to estimate the Gonadosomatic (GI) and hepatosomatic (HI) indexes. In females, the indexes were also compared to the degree of development of the ovaries. In males the Gl showed a peak of gonadal development in the autumn $(p<0.05)$, just when the HI showed a decrease $(p<0.05)$. Females showed a rise in the $\mathrm{Gl}$ at the end of summer and beginning of autumn $(p<0.05)$. In females, $\mathrm{Gl}$ values increased as the ovary matured. In A. platensis, for both males and females, the $\mathrm{HI}$ never showed values lower than the $\mathrm{Gl}$, which may indicate that these aeglids show a different pattern of energy utilization from other decapods, where as gonadal development peaks the $\mathrm{HI}$ decreases markedly.

KEY-WORDS. Aeglids; gonadosomatic index; reproduction.
\end{abstract}

\begin{abstract}
RESUMO. Dinâmica do desenvolvimento gonadal de Aegla platensis Schmitt (Decapoda, Anomura, Aeglidae). Uma maneira de estimar o desenvolvimento gonadal ao longo do ciclo reprodutivo é observar o crescimento das gônadas em relação aos órgãos utilizados para o estoque de energia. O objetivo desse estudo foi acompanhar os índices gonadossomático e hepatossomático durante o ciclo reprodutivo de Aegla platensis Schmitt, 1942.

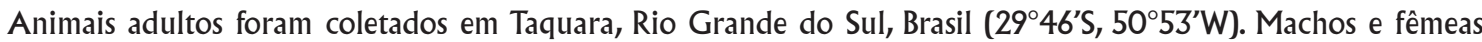
foram pesados e dissecados, gônadas e hepatopâncreas (HP) foram retirados e pesados para obtenção dos índices gonadossomático (IG) e hepatossomático (IH). Nas fêmeas, os índices também foram comparados com o grau de desenvolvimento dos ovários. Nos machos o IG mostrou um pico de desenvolvimento gonadal no outono $(\mathrm{p}<$ $0,05)$, quando os valores do IH diminuíram $(p<0,05)$. Fêmeas mostraram um aumento do IG no final do verão e início do outono $(\mathrm{p}<0,05)$ e os valores do IG aumentaram à medida que o ovário tornava-se maduro. Em $A$. platensis, tanto nos machos como nas fêmeas, os valores do IH nunca mostraram valores mais baixos que o IG, o que pode indicar que esses aeglídeos apresentam um padrão de utilização de energia diferente dos outros decápodos, onde à medida que o desenvolvimento gonadal aumenta os valores do $\mathrm{IH}$ diminuem marcadamente. PALAVRAS-CHAVE. Aeglídeos; índices gonadais; reprodução.
\end{abstract}

The study of the reproductive cycle of a species includes several peculiar aspects that require different lines of investigation. In the characterization of maturity, fecundity, moulting, and life cycle, reproductive period, gonadal development and egg development, periodic population samples are needed (GonZÁles-GuRRIARÁN 1985).

During the gonadal development of decapods, there are modifications in the structure of the gonads, which includes gonadal cell modifications, growth of gametes to maturation, ovulation, and oviposition in the case of females (GrASSÉ 1994). In males the spermatogenesis is characterized by the development of germinative cells of spermatogonia, passing through primary and secondary spermatocytes until mature spermatids, and the latter in mature spermatozoa (KROL et al. 1992).

All these modifications in the structure of the gonads require a great amount of energy. Lipid deposition during maturation is crucial to gonad development and reproduction, and it is essential to the embryo growth (CAVAlLI et al. 2001, Krol et al. 1992). The yolk consists of water, protein, and lipids; it is a structural component in tissue formation and a necessary nutrient for the developing embryo (KROL et al. 1992). Vitellogenesis is characterized by a rapid deposition of yolk and other proteins in the oocyte, which results in a rapid increase in its diameter (EASTMAN-Reks \& Fingerman 1985). 
The main storage organ of organic and inorganic reserves in decapods is the hepatopancreas. It is used in the synthesis and secretion of digestive enzymes and in carbohydrate metabolism, among other functions (MACLAUGHLIN 1983).

Seasonality of gonadal development in the somatic tissues is associated with the stocking of organic and mineral reserves which are carried to the gonads during gametogenesis (LAWRENCE 1976). Therefore, it is expected that during gonadal development, the energy reserves of the hepatopancreas are used, so that the gonadosomatic and hepatosomatic index values are expected to vary inversely to one another.

In the study of gonadal development as well as in the estimate of maturity, the gonadal index is a qualitative method of maturity determination that is often used (HAEFNER \& SPAARGAREN 1993, Chu 1995, López-Greco \& Rodríguez 1999). Besides estimating maturity, the gonadosomatic index expresses, as a percentage, how much the gonad represents in the total weight of the body of the animal; and it is an indicator of the functional condition of the ovaries (VAZzoler 1996). In studies of gonadal development, the gonadal indexes are often used together with the indexes of organs that store energy; these organs often fluctuate in size time in a similar way to the gonads (GRANT \& TYLER 1983).

Aegla platensis Schmitt, 1942 is a species with wide geographic distribution, found in several regions of Argentina, Paraguay and Uruguay. In Brazil it occurs in southwestern Santa Catarina and in most of the state of Rio Grande do Sul except its northeast region (Bond-Buckup \& Buckup 1999). This species has a long reproductive period, with ovigerous females found year-round (BUENo \& BOND-BUCKUP 2000). More profound studies of the reproductive cycle of A. platensis, such as analysis of gonadal development, fecundity and maturity, are lacking.

In view of the lack of information about the gonadal development of $A$. platensis, this research aimed to verify the relationships between gonads and hepatopancreas, as well as following the gonadal development during the course of a year. This paper is part of a bigger study about the reproductive aspects of A. platensis, where the description of the males and females' gonads and relative growth were made.

\section{MATERIAL AND METHODS}

Adult animals were collected monthly from July 2003 through June 2004 in the Mineiro Creek, in the basin of the Gravataí River, Taquara, Rio Grande do Sul, Brazil (29² $46^{\prime}$ S, $\left.50^{\circ} 53^{\prime} \mathrm{W}\right)$. Whenever possible 10 males and 10 females were collected each month, with the exception of August 2003 and February 2004 when nine males were found; and March 2004 and May 2005 when only eight males were found.

Ovigerous females were excluded of the gonadal development analysis.

The animals had their cephalothorax length (CL) measured with a digital caliper to $0.01 \mathrm{~mm}$ accuracy, and weighed to an accuracy of $0.1 \mathrm{mg}$. The aeglids were dissected and had their gonads and hepatopancreas (HP) removed. In females, the ovaries and HP were weighed. As in previous histological observations it was noticed different degrees of vasa deferentia (VD) dilatation in males, the testes, VD, and HP were weighed.

The macroscopic degree of ovarian development was determined from ovary size and colour for each dissected female. The stages of maturation, from the least developed to the mature gonad, were distinguished as follows: Stage I) ovary beginning development/spent ovary, small and white, the posterior lobes reaching the first abdominal somite; Stage II) gonad yellow, with posterior lobes reaching the first abdominal somite; Stage III) ovary orange, the lobes slightly wider than the former stages and of similar length; Stage IV) gonad fully developed, ovary red and the lobes visually wider than the other stages, may reach the third abdominal somite.

The gonadosomatic index (GI) and hepatosomatic index (HI) were calcutated as follows (GRANT \& TYLER 1983, VAZZOLER 1996): $\mathrm{Gl}=\mathrm{GW} / \mathrm{TW} \times 100$, where $\mathrm{GW}$ is the gonad weight and TW is the total weight of the animal. $\mathrm{HI}=\mathrm{HW} / \mathrm{TW} \times 100$, where $\mathrm{HW}$ is the HP weight and TW is the total weight of the animal.

All data were analyzed using one-way ANOVA with Bio Estat software (AYREs et al. 1998); either to monthly and seasonal analysis the values of $\mathrm{GI}$ and $\mathrm{HI}$ were analyzed separately. When sample means were different, a Bonferroni test was used.

\section{RESULTS}

At the end of the 12-month study, 120 females and 114 males had been collected. The CL of females ranged from $10.11 \mathrm{~mm}$ to $19.25 \mathrm{~mm}$, and of males from $12.24 \mathrm{~mm}$ to 24.35 $\mathrm{mm}$. The weight of the females ranged from $50.8 \mathrm{mg}$ to 331.8 $\mathrm{mg}$, and of males from 98.6 to $972.6 \mathrm{mg}$.

Females with ovaries in the stage $\mathrm{V}$ were found during all months of the year (Fig. 1), as were males with the testes and vasa deferentia with advanced development (the last one with a great degree of dilatation).

Ovaries in stage III, were abundant, representing $40 \%$ of the ovaries of the collected females, followed by ovaries in stage II (23.7\%) and stages I and IV, each representing $17.8 \%$ of the females.

The lowest value of female GI (0.53) occurred in November (spring); the highest value (2.94) in March (late summer); the lowest value of $\mathrm{HI}$ (4.15) occurred in April, and the highest (6.93) in November. In males, the lowest value of GI (0.63) was in November and the highest (4.15) in April; the lowest value of HI (3.77) occurred in April and the highest (6.56) in September.

When data were grouped for a seasonal analysis, the gonadal development of females peaked at the end of the summer and in the autumn ( $p<0.05$ ), just when $\mathrm{HI}$ values were lowest ( $p<0.05$ ) (Fig. 2). In males, gonadal development was greatest in the autumn $(p<0.05)$, just when the HI was lowest $(p<0.05)$ (Fig. 3). Even when there was a rise in the values of $\mathrm{GI}$, these values never exceeded the HI. 

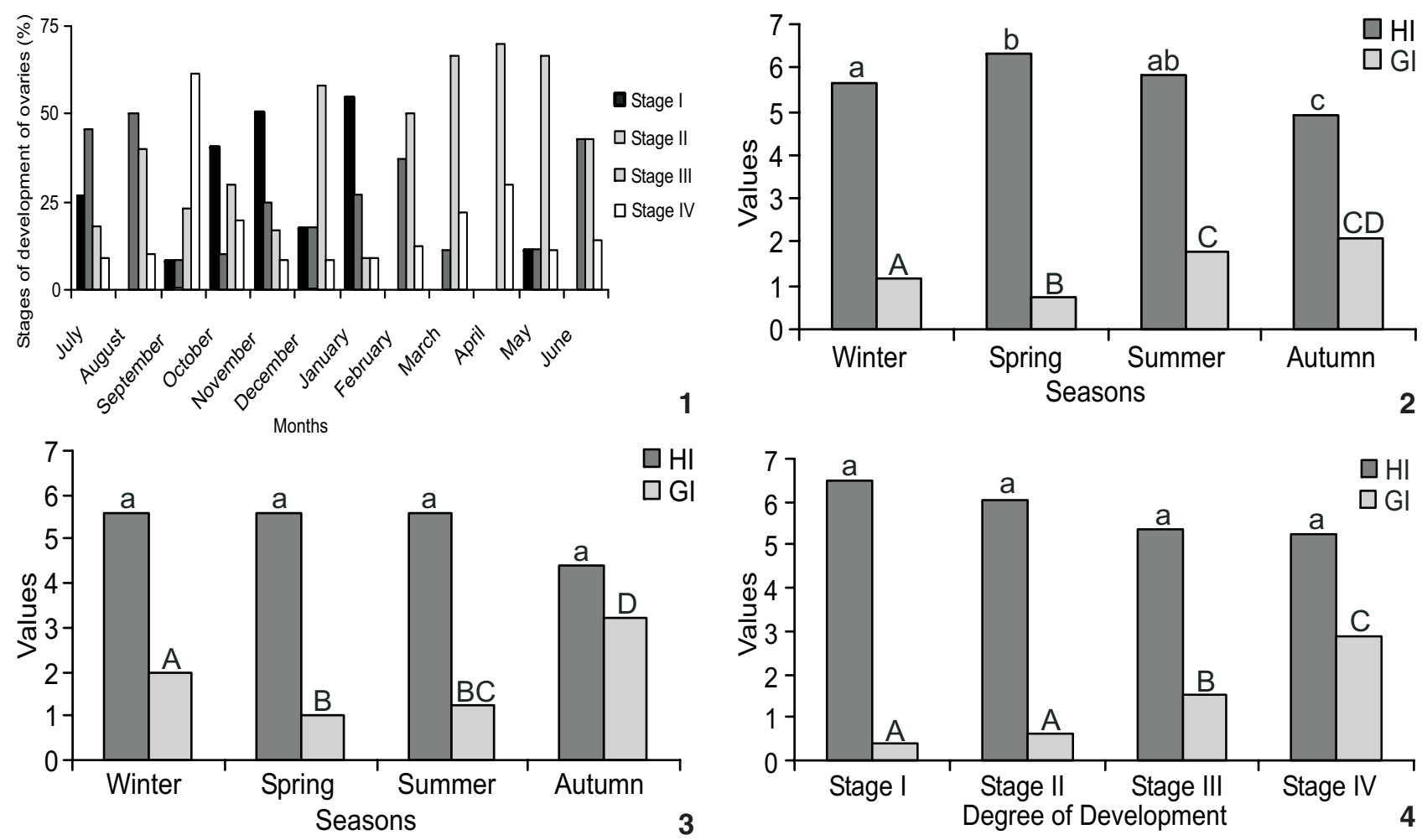

Figure 1. Aegla platensis collected in the Arroio do Mineiro: (1) percentage of the different stages of development of the ovaries; (2-3) seasonal hepatosomatic index (HI) and gonadosomatic index (GI) of (2) females and (3) males; (4) hepatosomatic index (HI) and gonadosomatic index $(\mathrm{Gl})$ of females in the different stages of ovary development. Different letters indicate significative differences ( $p$ $<0.05)$. Capital letters refer to $\mathrm{Gl}$ and small letters refer to $\mathrm{HI}$.

Considering the stages of development of the ovaries, GI increased and $\mathrm{HI}$ decreased as the ovaries developed ( $p<0.05$ ); there were no differences only in comparing stages I and II (Fig. 4). There was an overlap in GI values related to the degree of development of the ovaries and size of the females; females of different sizes showed different stages of ovary development.

\section{DISCUSSION}

The beginning of reproduction is a critical event in the life history of animals. This can be associated with the reproductive effort, which is defined by the proportion of energy that is allocated to reproduction (LóPEZ-GRECo \& Rodríguez 1999).

Often, decapod crustaceans have reproductive periods restricted to certain months of theyear, for example Macrobrachium borelli (Nobili, 1896), M. pottiuna (Müller, 1880), Palaemon pandaliformis (Stimpson, 1871), Chasmagnathus granulatus Dana, 1851, Cancer magister Dana, 1852 and U ca lactea (de Haan, 1835) (Bond \& Buckup 1982, Müller et al. 1996, López-Greco \& Rodríguez 1999, SWINEY \& SHIRLEY 2001, YAMAGUCHI 2001).

Some previously studied species of the genus Aegla demonstrated reproductive periods restricted to a particular season, such as A. laevis laevis (Latreille, 1818) from March to October;
A. odebrechtii paulensis Schmitt, 1942 from May/June to October; A. rostrata Jara, 1977 beggining in April and A. leptodactyla Buckup and Rossi, 1977 with a reproductive cicle beginning in April untill September (BAHAMONDE \& LóPEZ 1961, LóPEZ 1965, JARA 1977, Noro \& Buckup 2002). In this respect, A. platensis is different from most species of the genus Aegla, because ovigerous females are found year-round (Bueno \& BOND-Buckup 2000). This confirmed the results of this research, in which during all the months of sampling, males and females with gonads morphologically ready for reproduction were found.

The high proportion of ovaries in stage III during the study year may indicate that most of the population of $A$. platensis is in constant production of mature oocytes for reproduction; this is proven by the presence of females in the different stages of gonadal development throughout the year.

Although there were females with ripe gonads during the entire year, there was a peak in gonadal development (high GI value) in the beginning of autumn, when $68 \%$ of the females collected had ovaries in stage III. At this stage, the ovaries already contain many oocytes in secondary vitellogenesis with enough yolk for reproduction (Sokolowicz, personal observation); this is corroborated by the high values of GI in these 
months, so at this time the majority of the population is preparing the gonads for reproduction. Besides the high percentage of stage IV ovaries in September, it didn't result in great values in the seasonal analysis of gonadal development because this peak occurred only on this month of the season.

In decapods, the hepatopancreas is the major storage organ for organic reserves allocated to ovary development. The utilization of these reserves has been shown by several authors in different decapod species: M etapenaeus affinis (Milne Edwards, 1837) and Portunus pelagicus (Linnaeus, 1758) by Pillay \& NAIR (1973), Sesarma intermedia (de Haan, 1835) by Күомо (1988), Penaeus monodon (Fabricius, 1798) by MilLamena \& PAscual (1990), Crangon crangon (Linnaeus, 1758) by HaEFner \& SpAARGAREN (1993), Uca tangeri (Eydoux, 1835) by Mourente et al. (1994), M etapenaeus joyneri (Miers, 1880) by CHU (1995), and Chasmagnathus granulatus by López-Greco \& Rodríguez (1999). When males were also analyzed, none of these researches found correlations between the utilization of organic reserves during gonadal development.

Some studies also showed that the hepatopancreas may not be the main storage organ of organic reserves during reproduction; these studies did not demonstrate any correlation of this organ with gonadal development, as in Macrobrachium rosenbergii (de Man, 1879) (CAVALLI et al. 2001) and Uca annulipes (Milne Edwards, 1837) (PILlay \& NaIR 1973). In some cases, such as Aristeus antennatus (Risso, 1816), Parapenaeus Iongirostris (Lucas, 1846) and Nephrops norvegicus (Linnaeus, 1758) (RosA \& NunEs 2003), the HI values increase together with GI values in the reproductive season.

In females, during secondary vitellogenesis, synchronous growth of the oocytes occurs through endocytotic uptake of vitellogenin (CHARNIAUX-COTTON 1985). This accumulation of yolk in the ovary during preparation for reproduction can beobserved in the increase of the GI values in females as the ovary develops. Similar results were found in other crustaceans: Macrobrachium rosenbergii (CAVALLI et al. 2001), Aristeus antennatus, Parapenaeus longirostris and Nephrops norvegicus (RosA \& NunEs 2003).

The results of this study demonstrated that in Aegla platensis the pattern of utilization of the hepatopancreas reserves during gonadal development is followed for both males and females, because the HI values decreased significantly in the months which the GI values were higher. However, the hepatopancreas reserves were not completely used, because the $\mathrm{HI}$ values were always higher than the GI values.

Some hypotheses can be raised about this subject. These results may suggest that the animals are using another source of energy besides the hepatopancreas. During the process of gonadal development, much energy is lost to gamete production, especially in females, in which more energy is transferred to the gonads for yolk production; because of that it was expected that the $\mathrm{HI}$ values would be lower than in fact they were.

Several papers about biochemistry variations during reproduction have demonstrated that other tissues and organs, besides the hepatopancreas and ovary, can accumulate organic reserves, such as the hemolymph and the muscles (PILLAY \& Nair 1973, SpaArgaren \& Haefner 1994, Palacios et al. 2000, Cavalli et al. 2001, Rosa \& NunEs 2002).

The processes of reproduction and maturation seem to be influenced or even synchronized by seasonal feeding or food availability (ROSA \& NunES 2002). The year-round availability of food also may explain the low mobilization of reserves from the hepatopancreas to the gonad. In omnivorous species when food is available throughout the year, a reciprocal relationship between hepatopancreas and ovary may not be apparent (CLARKE 1982). A egla platensis feeds on plant detritus, immature insects, and several invertebrate groups; because of this it has been characterized as an omnivorous, generalist and opportunist species, feeding constantly, and showing completely full stomachs most of the time (Bueno \& Bond-Buckup 2004). Therefore, it can be expected that if the hepatopancreas reserves are used, this loss is compensated by direct gain from feeding, as suggested for Nephrops norvegicus (Tuck et al. 1997).

Another hypothesis that could explain the high values of $\mathrm{HI}$ as the ovary develops would be that the animal does not need to use a large amount of organic reserves because of the small number of extruded eggs compared to brachyurans, in which there is a great decrease of the hepatopancreas reserves during gonadal development. However, though the number of eggs in aeglids is lower, the amount of yolk in these eggs is much larger, since these animals show direct development and undergo the larval modifications while still inside the egg, which requires a large amount of energy.

Aegla platensis has a peculiar reproductive cycle compared to most decapods, in that it reproduces during the entire year. Though males and females with mature gonads are found in all months of the year, there is a peak in gonadal indexes during the autumn. This indicates that most animals of the population show gonadal preparation for the winter, when ovigerous females are more prevalent (BuEno \& Bond-Buckup 2000). These results, and the contemporaneous occurrence of females in the different stages of ovary development, indicate that there are animals in the different stages of the reproductive cycle at the same time, and thus the population is in constant gamete production.

\section{ACKNOWLEDGEMENTS}

Conselho do Aperfeiçoamento do Ensino Superior are thanked financial support, Programa de Pós-Graduação em Biologia Animal at UFRGS, and to Laura López-Greco (Universidade de Buenos Aires, Argentina) for the invaluable help.

\section{REFERENCES}

Ayres, M.; M. Ayres Jr; D.L. Ayres \& A.S. Santos. 1998. BioEstat, aplicações estatísticas nas áreas das ciências biológicas e médicas. Manaus, Sociedade Civil Mamirauá, MCT-CNPq, 193p.

Revista Brasileira de Zoologia 23 (4): 1153-1158, dezembro 2006 
Bahamonde, N. \& M.T. López. 1961. Estudios biológicos en la población de Aegla laevis laevis (Latreille) de El Monte. Investigaciones Zoológicas Chilenas, Santiago de Chile, 7: 19-58.

Bond, G. \& L. BuckUP. 1982. O ciclo reprodutor de Macrobrachium borelli (Nobili, 1896) e Macrobrachium potiuna (Müller, 1880) (Crustacea, Decapoda, Palaemonidae) e suas relações com a temperatura. Revista Brasileira de Zoologia, Curitiba, 42: 473-483.

Bond-Buckup, G. \& L. Buckup. 1999. Família Aeglidae (caranguejos anomuros), p. 362-382. In: L. BuckUP \& G. Bond-BucKuP (Eds). Os crustáceos do Rio Grande do Sul. Porto Alegre, Ed. Universidade Federal do Rio Grande do Sul, 503p.

Bond-Buckup, G. \& L. Buckup. 2000. Família Aeglidae, p. 23-142. In: G.A.D. M elo (Ed.). Manual de identificação dos Crustacea Decapoda de água doce do Brasil. São Paulo, Edições Loyola, Museu deZoologia, Universidade de São Paulo, 430p.

Bueno, A.A.P. \& G. Bond-Buckup. 2000. Dinâmica populacional de Aegla platensis Schmitt (Crustacea, Decapoda, Aeglidae). Revista Brasileira de Zoologia, Curitiba, 17: 43-49.

Bueno, A.A.P. \& G. Bond-Buckup. 2004. Natural diet of Aegla platensis Schmitt and Aegla ligulata Bond-Buckup \& Buckup (Crustacea, Decapoda, Aeglidae) from Brazil. Acta Limnologica Brasileira, Botucatu, 16: 115-127.

Cavalli, R.O.; M. Tamtin; P. Lavens \& P. Sorgeloos. 2001. Variations in lipid classes and fatty acid content in tissues of wild Macrobrachium rosenbergii (de Man) females during maturation. Aquaculture, Amsterdam, 193: 311-324.

Charniaux-Cotton, H. 1985. Vitellogenesis and its control in Malacostracan Crustacea. American Zoologist, Thousand Oaks, 25: 197-206.

CHU, K.H. 1995. Aspects of reproductive biology of the shrimp Metapenaeus joyneri from the Zhujiang Estuary, China. Journal of Crustacean Biology, Lawrence, 15: 214-219.

Clarke, A. 1982. Lipid synthesis and reproduction in the polar shrimp Chorismus antarticus. Marine Ecology, Progress Series, Amelinghausen, 9: 81-90.

EASTMAN-REKS, S. \& M. Fingerman. 1985. In vitro synthesis of vitelline by the ovary of the fiddler crab, Uca pugilator. Journal of Experimental Zoology, New York, 233: 111-116.

GonZÁles-GurRIARÁn, E. 1985. Reproducción de la nécora Macropipus puber (L.) (Decapoda, Brachyura), y ciclo reproductivo en la Ría de Arousa (Galicia, N. W. España). Boletín del Instituto Español Oceanográfico, Madri, 2: 10-32.

Grant, A. \& P.A. TYler. 1983. The analysis of data in studies of invertebrate reproduction. I. Introduction and statistical analysis of gonad indices and maturity indices. International Journal of Invertebrate Reproduction, Amsterdam, 6: 259-269.

GrASSÉ, P.P. 1994. Traité de Zoologie: Anotomie, Systématique, Biologie. Tome VII. Crustacés; fascicule I: Morphologie, Physiologie, Reproduction, Systématique. Paris, Masson, 917p.
HaEfNer, P.A. \& D.H. SpaARgaren. 1993. Interactions of ovary and hepatopancreas during the reproductive cycle of Crangon crangon (L.). I Weight and volume relationships. Journal of Crustacean Biology, Lawrence, 13: 523-531.

JARA, C. 1977. Aegla rostrata sp. nov., (Decapoda, Aeglidae), nuevo crustáceo dulceacuícola del sur de Chile. Studies on Neotropical Fauna Environment, Amsterdam, 12: 165-176.

KROL, R.M.; W.E. HaWkins \& R.M. Overstreet. 1992. Reproductive Components, p. 295-343. In: F.W. HaRRISOn (Ed.). Microscopic Anatomy of Invertebrates. New York, Willy-Lizz, vol. 10, 459p.

Kүомо, J. 1988. Analysis of the relationship between gonads and hepatopancreas in males and females of the crab Sesarma intermedia, with reference to resource use and reproduction. Marine Biology, Berlin, 97: 87-93.

Lawrence, J.M. 1976. Patterns of lipid storage in postmetamorphic marine invertebrates. American Zoologist, Thousand Oaks, 16: 747-762.

Lopez, M.T. 1965. Estúdios biológicos em Aegla odebrechtii paulensis Schmitt. Boletim de Zoologia, Faculdade de Filosofia, Ciências e Letras, São Paulo, 25: 301-314.

López-GreCo, L.S. \& E.M. Rodríguez. 1999. Annual reproduction and growth os adult crabs Chasmagnathus granulata (Crustacea, Brachyura, Grapsidae). Cahiers de Biologie Marine, Paris, 40: 155-164.

MacLaUghlin, P.A. 1983. Internal Anatomy, p. 1-52. In: D.E. Bliss (Ed.). The biology of crustacea. New York, Academic Press, vol. 5, 469p.

Millamena, O.M. \& F.P. Pascual. 1990. Tissue lipid content and fatty acid composition of Penaeus monodon Fabricius broodstock from the wild. Journal of the World Aquaculture Society, Baton Rouge, 21: 116-121.

Mourente, G.; A. Medina; S. Gonzáles \& A. Rodriguez. 1994. Changes in the lipid class and fatty acid contents in the ovary and midgut gland of the female fiddler crab Uca tangeri (Decapoda, Ocypodiadae) during maturation. Marine Biology, Berlin, 121: 187-197.

Müller, Y.M.R.; E.M. NazARI; C.M. Bressan \& D. Ammar. 1996. Aspectos da reprodução de Palaemon pandaliformis (Stimpson) (Decapoda: Palaemonidae) no manguezal de Ratones, Florinanópolis, SC. Revista Brasileira de Zoologia, Curitiba, 13: 633-642.

Noro, C.K. \& L. Buckup. 2002. Biologia reprodutiva e ecologia de Aegla leptodactyla Buckup \& Rossi (Crustacea, Anomura, Aeglidae). Revista Brasileira de Zoologia, Curitiba, 19: 10631074.

Palacios, E.; A.M. Ibarra \& I.S. Racotta. 2000. Tissue biochemical composition in relation to multiple spawning in wild and pond-reared Penaeus vannamei broodstock. Aquaculture, Amsterdam, 185: 353-371.

PILlAY, K.K. \& N.B. NaIR. 1973. Observations on the biochemical changes in the gonads and other organs of Uca annulipes, portunus pelagicus and Metapenaeus affinis (Decapoda: 
Crustacea) during the reproductive cycle. Marine Biology, Berlin, 18: 167-198.

RosA, R. \& M.L. Nunes. 2002. Biochemical changes during the reproductive cycle of the deep-sea decapod Nephrops norvegicus on the south coast of Portugal. Marine Biology, Berlin, 141: 1001-1009.

RosA, R. \& M.L. Nunes. 2003. Changes in organ indices and lipid dynamics during the reproductive cycle of Aristeus antennatus, Parapenaeus longirostris, and Nephrops norvegicus (Decapoda) from the portuguese south coast. Crustaceana, Leiden, 75: 1095-1105.

SpaARgaren, D.H. \& P.A. HAEFner, JR. 1994. Interactions of ovary and hepatopancreas during the reproductive cycle of Crangon crangon (L.). II. Biochemical relationships. Journal of Crustacean Biology, Lawrence, 14: 6-19.

SWiney, K.M. \& T.C. Shirley. 2001. Gonad development of southeastern Alaskan dungeness crab, Cancer magister, under laboratory conditions. Journal of Crustacean Biology, Lawrence, 21: 897-904.

Tuck, I.D.; A.C. TAYLoR \& R.J.A. AtKinson. 1997. Biochemical composition of Nephrops norvegicus; changes associated with ovary maturation. Marine Biology, Berlin, 129: 505-511.

VAZzoler, A.E.A. DE M. 1996. Biologia da reprodução de peixes teleósteos: teoria e prática. Maringá, SBI, Editora Universidade Estadual de Maringá, 169p.

YAMAGUCHI, T. 2001. Seasonal change of the hapatopancreas index in the males of the fiddler crab, Uca lactea. Crustaceana, Leiden, 74: 627-634.

Received in 21.VI.2006; accepted in 06.XI.2006. 